\title{
Ferryl and Ferrate Species: Mössbauer Spectroscopy Investigation
}

\author{
Virender K. Sharma, ${ }^{1, *}$ Radek Zboril ${ }^{2}$
}

1 Department of Environmental and Occupational Health, School of Public Health, Texas A\&M University, 1266 TAMU, College Station, Texas 77843, USA
2 Regional Center of Advanced Materials and Technologies, Palacky University in Olomouc, 17. listopadu 1192/12, 771 46 Olomouc, Czech Republic
${ }^{*}$ Corresponding author's e-mail address: vsharma@sph.tamhsc.edu

RECEIVED: June 18, 2015 * ACCEPTED: July 27, 2015

THIS PAPER IS DEDICATED TO DR. SVETOZAR MUSiĆ ON THE OCCASION OF HIS 70 ${ }^{\mathrm{TH}}$ BIRTHDAY

\begin{abstract}
High-valent iron species of oxidation states $+4,+5$, and +6 , have been involved as intermediates in enzymatic reactions, in green organic synthesis, and in purification and disinfection of water. Many of these species have been synthesized to understand their role in different systems, which include ferryl complexes (oxoiron(IV) $\left(\mathrm{Fe}^{\mathrm{IV}}=\mathrm{O}\right)$, oxoiron(V) ( $\left.\mathrm{Fe}^{\mathrm{V}}=\mathrm{O}\right)$ ), iron(IV $\left./ \mathrm{V} / \mathrm{VI}\right)$-nitride complexes, and ferrates $\left(\left(\mathrm{Fe}^{\mathrm{V} I} \mathrm{O}_{4}{ }^{2-}, \mathrm{Fe}(\mathrm{VI}), \mathrm{Fe}^{\mathrm{V}} \mathrm{O}_{4}{ }^{3-}, \mathrm{Fe}(\mathrm{V})\right.\right.$, and $\left.\mathrm{Fe}^{\mathrm{IV}} \mathrm{O}_{4}{ }^{4-}, \mathrm{Fe}(\mathrm{IV})\right)$. Ferryl and iron-nitride complexes have organic ligands surrounded at the iron center and are soluble in non-aqueous solvent. Comparatively, ferrate species are tetraoxyanions and are soluble in water. This paper presents Mössbauer spectroscopy as a tool to distinguish different oxidation states of iron and to gain information on the geometry and structure of high-valent iron complexes. Examples are given to demonstrate the application of Mössbauer spectroscopy in learning mechanisms of thermal decomposition of ferrates, encapsulation of heavy metals by ferrates, and oxidation of thiols by ferrates.
\end{abstract}

Keywords: high-valent iron species, biological remediation, rapid-freeze technique, Mössbauer spectroscopy.

\section{INTRODUCTION}

RON is an earth abundant element that occurs in +2 and +3 oxidation states, $\mathrm{Fe}(\mathrm{II})$ and $\mathrm{Fe}(\mathrm{III})$, in the natural environment. However, more electron-deficient iron with oxidation states of $+4,+5$, and +6 have been invoked in biological, industrial, and waste treatment reactions. ${ }^{[1-4]}$ For example, the activation of dioxygen to oxidize unactivated $\mathrm{C}-\mathrm{H}$ bond of the substrates involved oxoiron(IV) $\left(\mathrm{Fe}^{\mathrm{IV}}=\mathrm{O}\right)$ and oxoiron $(\mathrm{V})\left(\mathrm{Fe}^{\mathrm{V}}=\mathrm{O}\right)$, generally called ferryl species. ${ }^{[5-9]}$ Figure 1 represents characterization of the three kinds of high-valent iron-oxo active sites in haem and non-haem enzymes. In the first kind, haem-comprising enzymes contain mononuclear iron-protophrin IX active sites. ${ }^{[1]}$ The second and the third kinds of enzymes involve mononuclear and diiron centers. The Fe(II) centers in the enzymes can perform different two-electron oxidation reactions. These high-valent iron species may also be participating in other reactions including epoxidation, decarboxylation, and cyclization. ${ }^{[6,10]}$
In addition to iron oxo species, high-valent ironnitrido complexes have also been suggested to play significant role in nitrogenase enzyme reactions and industrial Haber-Bosch process. ${ }^{[11-13]}$ Figure 2 depicts the postulated intermediates with iron-nitrogen multiple bonds. ${ }^{[1]}$ At the single iron site, reduction of nitrogen may occur. Importantly, binding of nitrogen and also the cleavage happen at this iron site, which ultimately lead to the generation of ammonia and the formation of multiple iron-nitrogen bonds (Figure 2). Similar imidoiorn(IV) porphyrin species as intermediates have also been suggested in enzyme-catalyzed nitrogen-atom transfer reactions. ${ }^{[14]}$

Because of implication of high-valent iron species in biological transformation, many model iron(IV) and iron(V) complexes have been synthesized to comprehend mechanisms of the catalytic cycles of enzymatic reactions. Most of these complexes have organic ligands around the iron center. Investigation of such high-valent iron species have been carried out in non-aqueous environment. Because of 


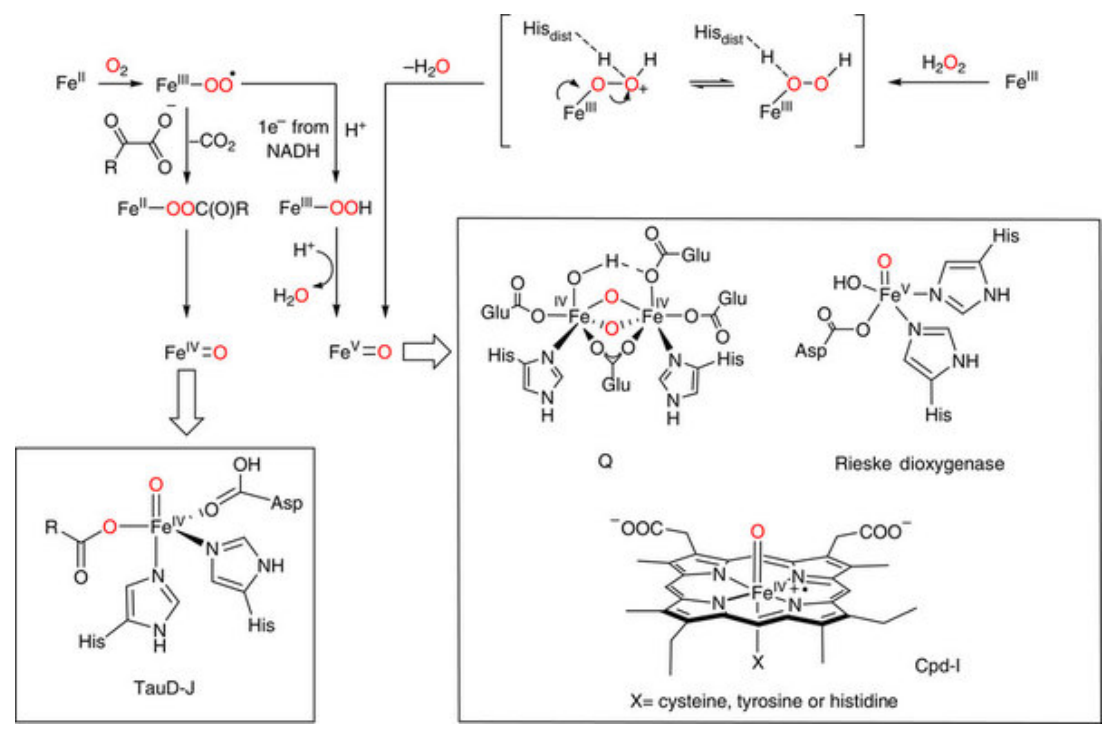

Figure 1 The structures in the boxes depict high-valent intermediates of the enzymatic reactions; TauD-J: intermediate J of taurine dioxygenase, $\mathrm{Q}$ : intermediate $\mathrm{Q}$ of soluble methane monooxygenase, Cpd-I: Compound-I intermediates of iron containing haem enzymes, like catalase, peroxidase or cytochrome-P450; His: histidine; Hisdist: distal histidine; Asp: asparagine; Glu: glutamic acid. Adapted from Hohenberger et al. ${ }^{[1]}$ with the permission of Macmillian Publishers Limited.

their instability at room temperature, studies have been restricted to low temperatures. ${ }^{[1,10]}$

Other high-valent iron compounds are tetraoxyanions, which are commonly called ferrates $\left(\mathrm{Fe}^{\mathrm{Vl}} \mathrm{O}_{4}{ }^{2-}, \mathrm{Fe}(\mathrm{VI})\right.$, $\mathrm{Fe}^{\mathrm{V}} \mathrm{O}_{4}{ }^{3-}, \mathrm{Fe}(\mathrm{V})$, and $\left.\mathrm{Fe}^{\mathrm{IV}} \mathrm{O}_{4}{ }^{4-}, \mathrm{Fe}(\mathrm{IV})\right)$. Ferrates are soluble in water and have a broad portfolio of applications in energy materials, green organic synthesis, and treating merging contaminants and toxins in water. ${ }^{[15-19]} \mathrm{Fe}(\mathrm{VI})$ can perform multimodal actions in water treatment which include oxidation, disinfection, and coagulation. The benign nature of ferrates has advantages over other conventional disinfectants (e.g. chlorine, chloramine, and chlorine dioxide). [20]

This paper presents some examples on the application of Mössbauer spectroscopy to characterize ferryl and ferrate species. A progress on their identification as intermediates of oxidative reactions is also given.

\section{IRON-OXO COMPLEXES}

A series of high-valent oxoiron(IV) and oxoiron(V) have been synthesized in the last three decades. ${ }^{[6,9]}$ Complexes of oxoiron(IV) containing haem and non-haem ligands have spin (S) of 1 and 2. ${ }^{57} \mathrm{Fe}$ Mössbauer spectroscopy was utilized to probe locally the iron center. The isomer shifts $(\delta)$, which relates to oxidation state (or electron density) of the iron nucleus of haem and non-haem oxoiron species, are shown in Figure 3. The quadrupole splitting $\left(\Delta E_{Q}\right)$ is determined by the electric field gradient at the iron center. Information on molecular geometry and electronic ground state can be obtained from the values of $\Delta E_{\mathrm{Q}}$. Other parameter

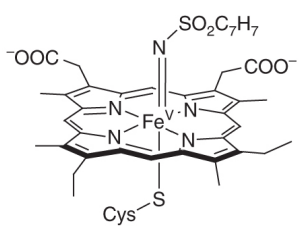

b
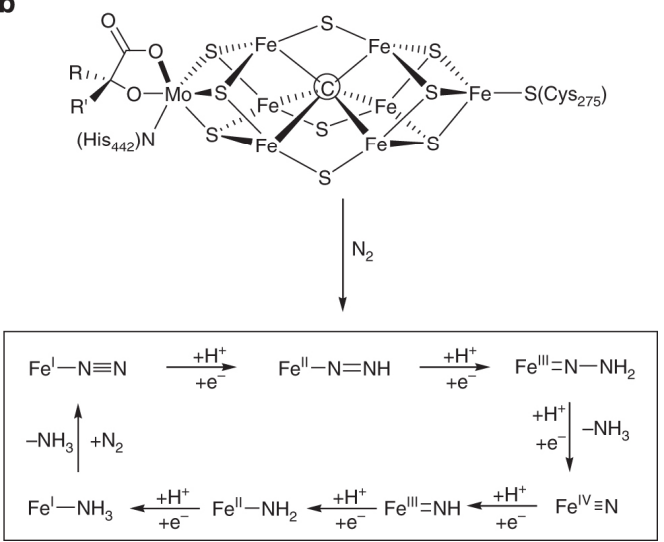

Figure 2. The proposed structures have inspired studies on model iron-nitrido and imido complexes. (a) Structure of the iron(IV) imido porphyrin intermediate that has been invoked for cytochrome-P450 catalysed nitrogen group transfer reactions; (b) The iron molybdenum cofactor of the nitrogenase enzyme with a central carbide, (C) and the proposed intermediates (scheme in the box) of the dinitrogen activation process occurring at a single iron site. Adapted from Hohenberger et al. ${ }^{[1]}$ with the permission of Macmillian Publishers Limited. 


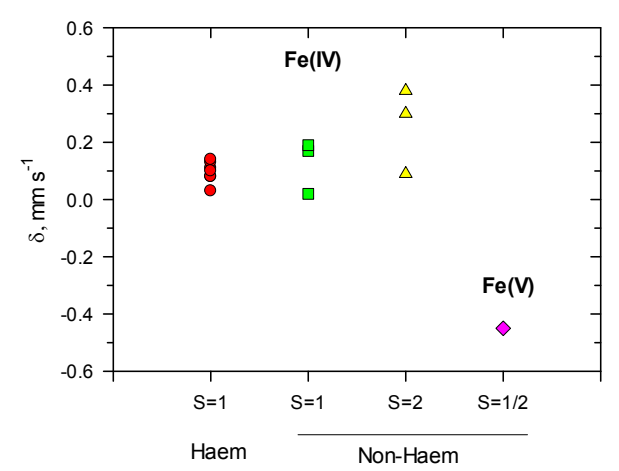

Figure 3. Isomer shifts of high valent iron-oxo complexes of the haem and non-haem systems. Data were taken from Hohenberger et al. ${ }^{[1]}$

of the Mössbauer spectrum is nuclear hyperfine tensor (A), which is helpful in understanding the electronic structure of paramagnetic species. Values of $\delta$, collected under zero-field for both haem and non-haem, belong to iron(IV) oxidation state (Figure 3). However, collection of Mössbauer spectra under applied magnetic field revealed different spin states of iron(IV) complexes. In the haem system values of $\Delta E_{\mathrm{Q}}$ were positive $\left(0.90-2.06 \mathrm{~mm} \mathrm{~s}^{-1}\right)$ whereas non-haem systems had some negative values of $\Delta E_{\mathrm{Q}}\left(-0.22-1.53 \mathrm{~mm} \mathrm{~s}^{-1}\right){ }^{[1]}$ The difference between $S=1$ and $S=2$ of oxoiron(IV) complexes was elucidated from their A tensor parameters. Heam enzymes with $S=1$ had "two large negative values" and "one small negative value". Comparatively, non-haem systems having $S=2$ had "three large negative" A tensors. ${ }^{[1]}$ This $S=2$ configuration may correspond to weak ligand field on the iron center. ${ }^{[21]}$

The oxoiron( $\mathrm{V})\left(\mathrm{d}^{3}\right)$ complex was obtained by oxidizing Fe ${ }^{\text {III }}$ complex ([(TAML)Fe $\left.{ }^{\text {III }}\left(\mathrm{H}_{2} \mathrm{O}\right)\right]^{-}$, TAML = tetraamido macrocyclic ligand) with meta-chloroperbenzoic acid in $n$-butyronitrile at $-60{ }^{\circ} \mathrm{C} .{ }^{[22]}$ The low negative isomer shift of $-0.42 \mathrm{~mm} \mathrm{~s}^{-1}$ was obtained (Figure 3). A much larger value of $\Delta E_{\mathrm{Q}}=4.24 \mathrm{~mm} \mathrm{~s}^{-1}$ for oxoiron(V) species than that of oxoiron(IV) complexes was evaluated from the Mössbauer spectrum. The spin of $S=1 / 2$ for oxoiron(V) was revealed by the electron paramagnetic resonance (EPR) spectrum.

\section{IRON-NITRIDO COMPLEXES}

Studies on the synthesis of iron-nitro compounds having valence states of $+4,+5$, and +6 have been reported. $[1,11,13]$ Figure 4 shows the example of the scheme in which different high-valent species have been demonstrated. Details of the scheme has been given elsewhere. ${ }^{[13]}$ Briefly, this scheme shows the photolysis of species $\mathbf{1}$ yielded compound $\mathbf{2}$ ( $\mathrm{Fe}(\mathrm{V})$-nitrido complex). When species $\mathbf{3}$ was reduced, the compound $\mathbf{4}$ having +4 oxidation state of iron (Fe(IV)-nitrido complex) was obtained. The photochemical reaction of compound 4 yielded species $\mathbf{5}$. The parameters of the Mössbauer spectrum of compound $\mathbf{5}$ were $\delta=$ $0.11 \mathrm{~mm} \mathrm{~s}^{-1}$ and $\Delta E_{\mathrm{Q}}=1.92 \mathrm{~mm} \mathrm{~s}^{-1}$; indicated +6 formal oxidation state (i.e. Fe(VI)-nitrido complex) (Figure 4). The assignment of +6 oxidation state to species 5 was further confirmed by correlating the isomer shifts to the oxidation state of octahedral complexes having similar ligands, but different electronic configurations ranging from $d^{6}$ to $d^{2}$. Almost linear relationship between isomer shifts and oxidation state of these complexes was observed confirming assignments of different iron valence states of species in the scheme (Figure 4).

\section{FERRATES}

Numerous alkali and alkaline earth salts of $\mathrm{Fe}(\mathrm{IV}), \mathrm{Fe}(\mathrm{V})$, and $\mathrm{Fe}(\mathrm{VI})$ have been prepared and were investigated using zero-field and in-field Mössbauer spectroscopy. Isomer shifts of different salts of $\mathrm{Fe}(\mathrm{VI})$ (e.g. $\mathrm{Na}_{2} \mathrm{FeO}_{4}, \mathrm{~K}_{2} \mathrm{FeO}_{4}$, $\mathrm{Rb}_{2} \mathrm{FeO}_{4}, \mathrm{CS}_{2} \mathrm{FeO}_{4}$, and $\left.\mathrm{BaFeO}_{4}\right)$ varied little $(-0.87$ to

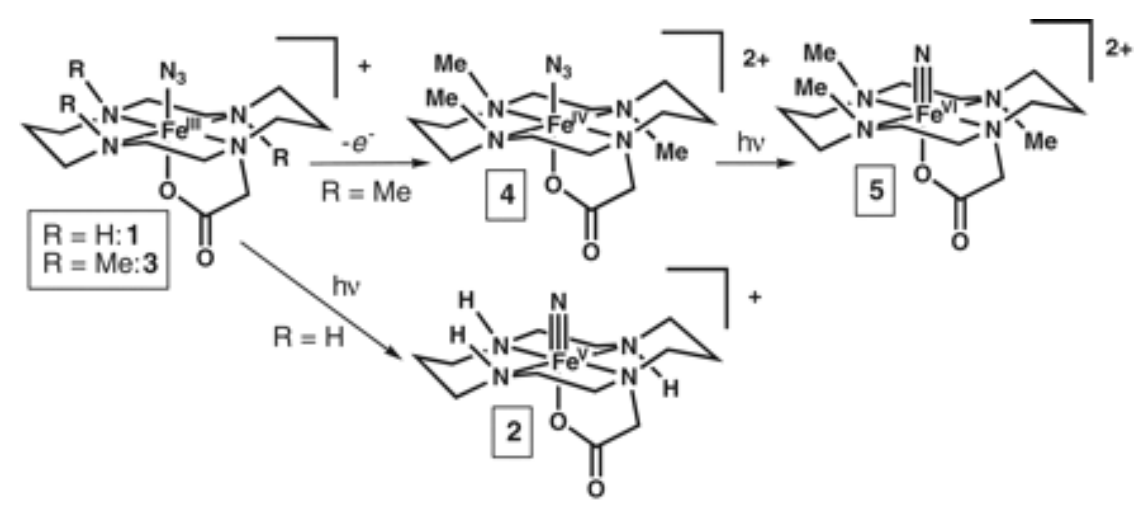

Figure 4 Scheme of generation of high-valent iron-nitrido species.Adapted from Berry et al. ${ }^{[13]}$ with the permission of HighWire Press. 


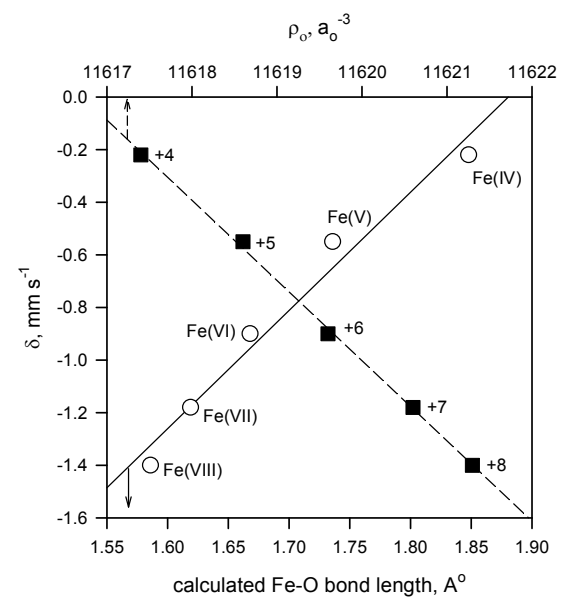

Figure 5. Relationships of isomer shifts with the Fe-O bond distances and electron density on the iron nucleus $\left(\rho_{0}\right)$ of ferrates. Adapted from Sharma et al. ${ }^{[24]}$ with the permission of Wiley Inc.

$-0.91 \mathrm{~mm} \mathrm{~s}^{-1}$ ); suggesting weak influence of the counterions on the iron center of the tetraoxyanions. Mössbauer spectroscopy was also applied to establish the oxidation states of iron in $\mathrm{Na}_{4} \mathrm{FeO}_{4}$ and $\mathrm{K}_{3} \mathrm{FeO}_{4}$. The variation of isomer shifts with oxidation state (OS) is given by Equation (1)

$$
\delta / \mathrm{mm} \mathrm{s}^{-1}=1.084-0.326 \times \mathrm{OS}
$$

Equation (1) allowed to estimate the isomer shifts of ferrate(VII) and ferrate(VIII) as -1.18 and $-1.40 \mathrm{~mm} \mathrm{~s}^{-1}$, relative to $\alpha-\mathrm{Fe}$, respectively. ${ }^{[23]}$

Significantly, density function theory calculations were carried out on ferrates with different valence states ranging from +4 to $+8 .{ }^{[23]}$ Figure 5 shows the relationship of isomer shift with electron density on the iron nucleus $\left(\rho_{0}\right)$ and $\mathrm{Fe}-\mathrm{O}$ bond length. ${ }^{[24]} \mathrm{A}$ decrease in $\mathrm{Fe}-\mathrm{O}$ bond distance with increase in oxidation state of iron from $\mathrm{Fe}(\mathrm{IV})$ to $\mathrm{Fe}(\mathrm{VIII})$ was observed. Values of isomer shifts had a negative relationship with $\rho_{\text {o }}$ whereas a positive linearity between isomer shift and bond distance was seen (Figure 5). The value of $\delta$ of $\mathrm{Fe}(\mathrm{VI})$ in ferrate is significantly lower than in nitride complex $\left(-0.90 \mathrm{~mm} \mathrm{~s}^{-1}\right.$ versus $\left.0.40 \mathrm{~mm} \mathrm{~s}^{-1}\right) .^{[13,24]}$ This is not surprising considering both species have different geometry and electronic structures. Ferrate(VI) has the tetrahedral structure while $\mathrm{Fe}(\mathrm{VI})$-nitrido complex possess the octahedral coordination. Furthermore, ferrate(VI) anion has four strong and covalent $\mathrm{Fe}-\mathrm{O}$ double bonds while in the nitride complex, only one strong Fe-N triple bond is present. A combination of these effects would influence the variation of isomer shifts in both ferrate and $\mathrm{Fe}(\mathrm{VI})$-nitride complex species.
The isomer shift values, shown in Figure 5, were used in studying the decomposition of salts of $\mathrm{Fe}(\mathrm{IV}), \mathrm{Fe}(\mathrm{V})$, and $\mathrm{Fe}(\mathrm{VI})$ under humid and thermal conditions.[25,26] The encapsulation of arsenic and heavy metals by iron(III) oxide nanoparticles $\left(\gamma-\mathrm{Fe}_{2} \mathrm{O}_{3}\right)$, generated from $\mathrm{Fe}(\mathrm{VI})$, was investigated in detail by in-field Mössbauer spectroscopy. ${ }^{[27-29]}$ In the case of arsenic, the results clearly demonstrated that a significant portion of arsenic was embedded in the tetrahedral sites of the $\gamma-\mathrm{Fe}_{2} \mathrm{O}_{3}$ spinel structure.

Attempts have been made to identify intermediate(s) during the aqueous reactions of $\mathrm{Fe}(\mathrm{VI})$ with sulfurand nitrogen-containing compounds in order to distinguish one- and two-electron transfer reaction mechanisms. ${ }^{[30,31]}$ No direct evidence of intermediate valence state, Fe(IV) and $\mathrm{Fe}(\mathrm{VI})$, could be seen due to the highly instable character of such species, which most likely self-decomposed within $\sim 3 \mathrm{~s}$, a lag time of rapid-freezing off reaction mixtures $(\sim 3 \mathrm{~s})$. However, determination of final reduced iron species, $\mathrm{Fe}$ (II) or Fe(III) by Mössbauer spectroscopy was able to elucidate the mechanism of oxidation of thiols $(X)$ by $\mathrm{Fe}(\mathrm{VI})$ and is briefly described below.

The experimental stoichiometry of the oxidation of methionine $\left(\mathrm{CH}_{3} \mathrm{~S}\left(\mathrm{CH}_{2}\right)_{2} \mathrm{CH}\left(\mathrm{NH}_{2}\right) \mathrm{COO}^{-}\right.$Met) and cysteine $\left(\mathrm{HSCH}_{2} \mathrm{CH}\left(\mathrm{NH}_{3}{ }^{+}\right) \mathrm{COO}^{-}, \mathrm{Cys}\right)$ were described by Equations (2) and (3). ${ }^{[32]}$

$$
\begin{aligned}
& \mathrm{HFeO}_{4}^{-}+\mathrm{HSCH}_{2} \mathrm{CH}\left(\mathrm{NH}_{3}^{+}\right) \mathrm{COO}^{-}+\mathrm{H}_{2} \mathrm{O} \rightarrow \\
& \mathrm{Fe}(\mathrm{OH})_{2}+\mathrm{HS}\left(\mathrm{O}_{2}\right) \mathrm{CH}_{2} \mathrm{CH}\left(\mathrm{NH}_{3}^{+}\right) \mathrm{COO}^{-}+\mathrm{OH}^{-} \\
& 2 \mathrm{HFeO}_{4}^{-}+3 \mathrm{CH}_{3} \mathrm{~S}\left(\mathrm{CH}_{2}\right)_{2} \mathrm{CH}\left(\mathrm{NH}_{2}\right) \mathrm{COO}^{\prime}+3 \mathrm{H}_{2} \mathrm{O} \rightarrow \\
& 2 \mathrm{Fe}(\mathrm{OH})_{3}+3 \mathrm{CH}_{3} \mathrm{~S}(\mathrm{O})\left(\mathrm{CH}_{2}\right)_{2} \mathrm{CH}\left(\mathrm{NH}_{2}\right) \mathrm{COO}^{-}+2 \mathrm{OH}^{-}
\end{aligned}
$$

The Mössbauer spectra of the final frozen mixed solutions of $\mathrm{Fe}(\mathrm{VI})$ with either Cys or Met are shown in Figure 6. ${ }^{[31]}$ In case of Cys, The spectrum had one singlet and three doublets (Figure 6a); the singlet component with isomer shift of $-0.82 \mathrm{~mm} \mathrm{~s}^{-1}$ represents remaining non reacted $\mathrm{Fe}(\mathrm{VI})$, the doublet with isomer shift of $0.45 \mathrm{~mm} \mathrm{~s}^{-1}$ and quadrupole splitting of $0.77 \mathrm{~mm} \mathrm{~s}^{-1}$ is typical for high-spin $\mathrm{Fe}(\mathrm{III})$, and the two doublets with the same isomer shift of $0.90 \mathrm{~mm} \mathrm{~s}^{-1}$ and a huge quadrupole splitting of $3.72 \mathrm{~mm} \mathrm{~s}^{-1}$ and $3.00 \mathrm{~mm} \mathrm{~s}^{-1}$ is high-spin Fe(II). Comparatively, Mössbauer spectrum of the mixed frozen solution of $\mathrm{Fe}(\mathrm{VI})$ and Met had well resolved singlet and doublet components (Figure $6 \mathrm{~b}$ ); the singlet component with isomer shift of $-0.81 \mathrm{~mm} \mathrm{~s}^{-1}$ represents remaining non reacted $\mathrm{Fe}(\mathrm{VI})$ and the doublet with isomer shift of $0.45 \mathrm{~mm} \mathrm{~s}^{-1}$ and quadrupole splitting of $0.76 \mathrm{~mm} \mathrm{~s}^{-1}$ is usually for high-spin Fe(III). Importantly, no $\mathrm{Fe}$ (II) was seen in the oxidation of Met by $\mathrm{Fe}(\mathrm{VI})$. This indicates that $\mathrm{Fe}(\mathrm{II})$ was not involved as an intermediate during the oxidation of Met by $\mathrm{Fe}(\mathrm{VI})$. 
Overall, electron- transfer steps of the oxidation of Cys by $\mathrm{Fe}(\mathrm{VI})$ may be described by Equations (4) and (5). The formation of $\mathrm{Fe}(\mathrm{II})$ as the reduced product of $\mathrm{Fe}(\mathrm{VI})$ with Cys satisfies the observation of Mössbauer spectrum of Figure 6a.

$$
\begin{aligned}
& \mathrm{Fe}(\mathrm{VI})+\mathrm{Cys} \rightarrow \mathrm{Fe}(\mathrm{IV})+\mathrm{CysS}(\mathrm{O}) \\
& \mathrm{Fe}(\mathrm{IV})+\mathrm{Cys} \rightarrow \mathrm{Fe}(\mathrm{II})+\mathrm{Cys}(\mathrm{O})
\end{aligned}
$$

The electron-transfer steps of the oxidation of Met by $\mathrm{Fe}(\mathrm{VI})$ may be given as Equations (6)-(8). This reaction scheme is consistent with the observation of Mössbauer spectrum (i.e. $\mathrm{Fe}(\mathrm{III})$ as a final reduced species of $\mathrm{Fe}(\mathrm{VI})$ without the formation of Fe(II), see Figure 6b).

$$
\begin{aligned}
& \mathrm{Fe}(\mathrm{VI})+\mathrm{Met} \rightarrow \mathrm{Fe}(\mathrm{V})+\mathrm{Met}^{\bullet} \\
& \mathrm{Fe}(\mathrm{VI})+\mathrm{Met}^{\bullet} \rightarrow \mathrm{Fe}(\mathrm{V})+\mathrm{Met}(\mathrm{O}) \\
& 2 \mathrm{Fe}(\mathrm{V})+2 \mathrm{Met} \rightarrow 2 \mathrm{Fe}(\mathrm{III})+2 \mathrm{Met}(\mathrm{O})
\end{aligned}
$$

Interestingly, the reaction schemes, given by Equations (4), (5) and Equations (6)-(8), are in agreement
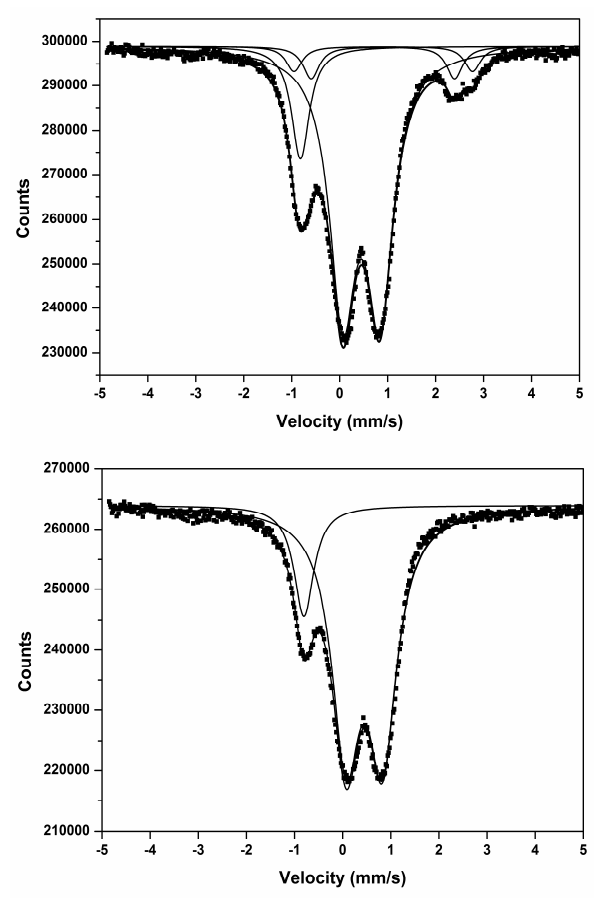

Figure 6. Mössbauer spectrum of the final frozen solution of mixtures of thiols with $\mathrm{Fe}(\mathrm{VI})$ for $3 \mathrm{~s}$. (a) Cysteine; (b) Methionine. Adapted from Sharma et al.[31] with the permission of Springers Inc. with the suggested initial electron transfer steps from the correlation of the rate constants with reduction potentials for the oxidation of Cys and Met by Fe(VI), respectively. ${ }^{[32]}$

\section{CONCLUSION}

Mössbauer spectroscopy method was one of the main tools to determine the oxidation states of iron in ferryl, ironnitride and ferrate species. Besides values of isomer shift $(\delta)$, quadrupole splitting $\left(\Delta E_{Q}\right)$ and nuclear hyperfine tensors (A) were determined for the complexes, which enhanced knowledge on the electric field gradient at the iron center, molecular geometry and electronic ground state as well as the electronic structure of paramagnetic species. Additionally, Mössbauer spectroscopy technique was successful in studying the mechanism of the oxidation of organosulfur compounds by ferrate(VI), however, freezing of samples of oxidative reactions within three seconds did not allow to identify the reactive intermediate iron species, $\mathrm{Fe}(\mathrm{V})$ and $\mathrm{Fe}(\mathrm{IV})$. A rapid freezing of reaction samples on the time scale of milliseconds would be needed to observe the intermediate iron species to comprehend reaction mechanisms.

Acknowledgment. V. K. Sharma acknowledges the partial support of United States National Science Foundation (CBET-1439314) for ferrate research. Authors gratefully acknowledge the support by the Operational Program Education for Competitiveness, European Social Fund (CZ.1.07/2.3.00/20.0155), the support by the Technology Agency of the Czech Republic "Competence Centers" (TE01020218), internal student grant IGA PrF 2014017 of Palacký University and the support by the project L01305 of the Ministry of Education, Youth and Sports of the Czech Republic.

\section{REFERENCES}

[1] J. Hohenberger, K. Ray, K. Meyer, Nature Commun. 2012, 3, 720.

[2] S. Fukuzumi, Dalton Trans. 2015, 44, 6696.

[3] P. P. Chandrachud, D. M. Jenkins, Tetrahedron Lett. 2015, 56, 2369.

[4] V. K. Sharma, R. Zboril, R. S. Varma, Acc. Chem. Res. 2015, 48, 182.

[5] M. Srnec, S. D. Wong, E. I. Solomon, Dalton Trans. 2014, 43, 17567.

[6] W. Nam, Y. Lee. S. Fukuzumi, Acc. Chem. Res. 2014, 47, 1146.

[7] A. R. McDonald, L. Que, Coord. Chem. Rev. 2013, 257, 414.

[8] S. Kundu, J. V. K. Thompson, A.D. Ryabov, T. J. Collins, J. Am. Chem. Soc. 2011, 133, 18546. 
[9] J. T. Groves. Nature Chem. 2014, 6, 89.

[10] K. Ray, F. Heims, M. Schwalbe, W. Nam. Curr. Opin. Chem. Biol. 2015, 25, 159.

[11] J. J. Scepaniak, C. S. Vogel, M. M. Khusniyarov, F. W. Heinemann, K. Meyer, J. M. Smith, Science 2011, 331, 1049.

[12] T. Petrenko, S. D. George, N. Aliaga-Alcalde, E. Bill, B. Mienert, Y. Xio, Y. Guo, W. Sturham, S.P. Cramer, K. Wieghardt, F. Neese, J. Am. Chem. Soc. 2007, 109, 11053.

[13] J. F. Berry, E. Bill, E. Bothe, S. George, B. Mienert, F. Neese, K. Wieghardt, Science 2006, 312, 1937.

[14] E. W. Svastits, J. H. Dawson, R. Breslow, S. H. Gellman, J. Am. Chem. Soc. 1985, 107, 6427.

[15] S. Licht, Energies 2010, 3, 960.

[16] L. Delaude, P. Laszlo, J. Org. Chem. 1996, 61, 6360.

[17] C. Kim, V. R. Panditi, P. R. Gardinali, R. S. Varma, H. Kim, V. K. Sharma, Chem. Eng. J. 2015, 279, 307.

[18] G. A. K. Anquandah, V. K. Sharma, V. R. Panditi, P. R. Gardinali, H. Kim, M. A. Oturan, Chemosphere 2013, 91, 105.

[19] V. K. Sharma, R. Zboril, T. J. McDonald, J. Environ. Sci. Health B 2014, 49, 212.

[20] W. Gan, V. K. Sharma, X. Zhang, L. Yang, X. Yang, J. Hazard. Mater. 2015, 292, 197.

[21] J. England, M. Martinho, E. R. Farquhar, J. R. Frisch, E. L. Bominaar, E. Munck, L. Que Jr, Angew. Chem., Int. Ed. 2009, 48, 3622.
[22] F. T. D. Oliveria, A. Chanda, D. Benerjee, X. Shan, S. Mondal, J. L. Que, E. L. Bominaar, E. Munck, T. J. Collins, Science 2007, 315, 835.

[23] O. Poleshchuk, N. Kruchkova, Y. Perfiliev, S. Dedushenko, J. Phys. Conference Series 2010, 217, 012041.

[24] V. K. Sharma, Y. Perfiliev, R. Zboril, L. Machala, C. Wynter in Mossbauer Spectroscopy: Applications in Chemistry, Biology, Industry, and Nanotechnology. (Eds.: V. K. Sharma, G. Klingelhofer, T. Nishida), John Wiley \& Sons Inc., Hoboken, New Jersey, 2013, pp. 505-517.

[25] L. Machala, R. Zboril, V. K. Sharma, Z. Homonnay, AIP Conf. Proc. 2008, 1070, 114.

[26] L. Machala, R. Zboril, V. K. Sharma, J. Filip, D. Jancik, Z. Homonnay, Eur. J. Inorg. Chem. 2009, 1060.

[27] J. Filip, R. A. Yngard, K. Siskova, Z. Marusak, V. Ettler, P. Sajdl, V. K. Sharma, R. Zboril, Chem. Eur. J. 2011, 17, 10097.

[28] R. Prucek, J. Tucek, J. Kolarik, I. Huskova, J. Filip, R. S. Varma, V. K. Sharma, R. Zboril, Environ. Sci. Technol. 2015, 49, 2319.

[29] R. Prucek, J. Tuček, J. Kolařík, J. Filip, Z. Marušák, V. K. Sharma, R. Zbořil, Environ. Sci. Technol. 2013, 47, 3283.

[30] V. K. Sharma, Z. Homonnay, K. Siskova, L. Machala, R. Zboril, Hyperfine Interact. 2014, 224, 7.

[31] V. K. Sharma, K. Siskova, L. Machala, R. Zboril. AIP Conf. Proc. 2012, 1489, 139.

[32] V. K. Sharma, G. W. Luther III, F. J. Millero, Chemosphere 2011, 82, 1083. 